\title{
James M. Harrison Award - 2012
}

\section{IUGS award honors outstanding achievement}

The James M. Harrison Award for Outstanding Achievement was established in 2004 by the IUGS Executive Committee as a means of honoring individuals who served the Union in an extraordinary way for a sustained period of time, but with no formal background in the Union such as officer status. The name of the award celebrates and honors the late Dr. James M. Harrison (19151990), an internationally respected Canadian geologist who became a founding father and, from 1961 to 1964, the first President of the IUGS.

Following a vote by the IUGS Executive Committee, the fourth recipient of the award is Professor Edward Derbyshire. IUGS President Alberto Riccardi will be presenting the award to Prof. Derbyshire during the $34^{\text {th }}$ International Geological Congress in Brisbane, Australia

\section{Citation for Prof. Edward Derbyshire}

"The James Harrison Award was set established in honor of the first IUGS President who served during the years 1961 - 1964. At that time, Edward Derbyshire had just arrived in Australia in order to take up his first Lectureship in the University of New South Wales, from which he moved to the newly launched Monash University in Melbourne in the following year. Over the next few years he worked in Tasmania and the Antarctic before returning to his alma mater (the University of Keele in the U.K.) in January 1967 as a Lecturer in Physical Geography.

Shortly thereafter, Edward Derbyshire began his foray into Chinese-European collaboration in key aspects of glacial and aeolian research that has lasted over 30 years. He soon moved to Leicester University to continue his mentoring career.

Edward held the position of SecretaryGeneral of INQUA from 1991 to 1995, during a time when INQUA was still an affiliated body of the IUGS. In order to give this office the attention that it deserved, he took early retirement form Leicester University at the age of 58. By this time, his increasing occupation with dryland research had brought him into IGCP 252 (Past and Future Evolution of Deserts: 1987-1991) as its U.K. national correspondent. He immediately recognized the unique qualities and potential of IGCP as a collaborative endeavor on the part of IUGS and UNESCO to the extent that he helped draw up, with Ashok Singhvi (Ahmedabad, India) and An Zhisheng (China), the successful IGCP 349 project

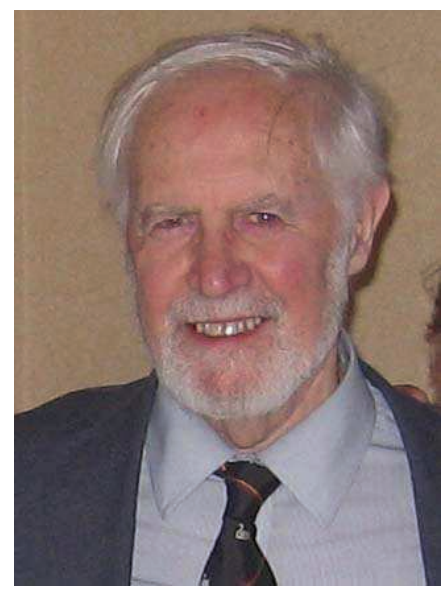

Prof. Edward Derbyshire

(Desert Margins and Palaeomonsoons since 135 ky BP: 1993-1997).

He became a member of the Scientific Board of the IGCP in 1995 and was appointed its Chairman from 1996 to 2001, the longest term yet served by an IGCP Chairperson. Also during the 1990s he actively contributed to the IUGS Commission on Environmental Management (COGEOENVIRONMENT) as a member of the Medical Geology Working Group.

Moving sideways into a less-related field of research, this time involving geologists together with medical scientists, including clinicians, toxicologists and epidemiologists, Edward was invited by Olle Selinus and Peter Bobrowsky to help design, and then co-lead with them, IGCP 454 (Medical Geology: 2000-2004). At the same time Edward continued to serve the interests of the geoscience community in the UK and the Union in his role as a member of the External Relations Committee of the Geological Society of London (incorporating the UK National Committees for the IUGS and the IGCP) from 1999 to 2006. Also during this decade he was extremely proactive in working with and promoting the best interests of several of the Union's affiliated organizations including but not limited to the Geological Society of London, AGID and the International Consortium on Landslides, to list a few.

Edward was involved early in a second co-initiative by IUGS and UNESCO, namely the International Year of Planet Earth. Initial discussions with Eduardo de Mulder and Henk Schalke in 2000 persuaded Edward of the nature and breadth, but also the challenges and sustainability of such an event. It was originally regarded as a United Nations Year lasting 12 months but, eventually, a triennium was demanded so as to maximize impact. In 2002, Edward was invited to chair the Science Programme of the 'Year', his first formal duty being to chair a panel of 21 distinguished scientists called to establish the 8 (but ultimately 10) scientific themes of extreme importance and relevance to human society; he served initially as a member of the management team and, later, as a member of the Board. He also contributed to the formative meeting in Celimontana, Italy, in 2005.

The IYPE triennium began formally in 2007. Edward's election as Secretary for Foreign and External Affairs of the Geological Society of London coincided with the International Year's triennium; this was very timely because his External Relations Committee also served as the U.K. National Committees for both IUGS and the IGCP. Throughout this time, also, Edward served as a member of the science committee of the U.K. National Commission for UNESCO, thus helping to ensure that international geosciences should not go unheard. He also served on the Science Programme Committee of the $33^{\text {rd }}$ International Geological Congress in Oslo, for which he also co-organised Symposium MGH-04. However, two TIAs (mini-strokes) in April 2008 prevented his attendance at the Congress.

Following his 'second retirement' in June 2010, he has continued his work on medical geology with emphasis on airborne natural mineral particles, thus keeping him in touch with international Geoscience institutions and a suite of mutually productive natural and medical scientists, as well as acting, with Eduardo de Mulder, as Series Editor of the legacy volumes that provide state of the art records of the International Year's ten themes.

Most recently Prof. Derbyshire generously and effectively compiled, edited and produced the $40^{\text {th }}$ Anniversary volume for IGCP which was released in Paris early in 2012. This seminal volume provides an historical overview and snapshot of the exceptional contributions of global scientists to the joint IUGS - UNESCO IGCP legacy.

The IUGS is extremely pleased to bestow the Harrison Medal and Award this year upon Prof. Derbyshire who exemplifies the 
voluntary service to the Union most cherished and appreciated by its members.

\section{Response by Edward Derbyshire}

Mr. President - Alberto Riccardi; Secretary-General - Peter Bobrowsky; Treasurer - William Cavazza; friends and colleagues; ladies and gentlemen

I was overwhelmed to hear from the President that I had been chosen by the Executive Committee of the IUGS as the 2012 recipient of the James M. Harrison Outstanding Achievement Award. I find it difficult to find the words to express adequately the honour and the feeling of privilege that comes with this distinguished award.

The early leadership of the IUGS, spurred on from 1961 by its first President, James Harrison, was energetic, imaginative and prescient concerning the approach to advancing the geosciences and the role that the Union might play such a process. One long-standing outcome from those early years was the International Geological Correlation Programme (IGCP) that, with the passage of time and changing shape of science, we know today as the International Geoscience Programme. The crucial action in this process was the agreement with UNESCO that IGCP would be a jointly sponsored initiative, a characteristic that has remained with it since its foundation in 1972. I had only a vague awareness of the IUGS until that date but, first, I became a Fellow of the Geological Society of London in that same year, then there followed James Harrison's article in 1978 on the history of the IUGS in the first issue of Episodes and, third, I began to follow certain IGCP projects, starting with IGCP 24 (1974-83) led by Šibrava (former Director of the UNESCO Division of Earth Sciences), but with much greater involvement from the mid-1980s

Toward the end of my 12-year membership (1994-2006) of the U.K. committees responsible for IUGS/IGCP, I became a member of the Scientific Board of the IGCP in 1995 and was appointed its Chairman from 1996 to 2001, the longest term yet served by an IGCP Chairperson. Those five years were frequently very testing but they were also stimulating and rewarding, largely because of the exceptional individuals from both IUGS and UNESCO with whom I worked, together with a widely cosmopolitan Board membership and tens of project leaders at the annual reviews every February. I owe a particular debt of gratitude for the support, wise council and good-humoured argument on many aspects of the IGCP and IUGSUNESCO relations to Wolfgang Eder
(Director and then Secretary), Vladislav Babuška (Secretary), Robert Missotten (Secretary), Andras Stolloszy-Nagy (Secretary, Hydrology Programme, UNESCO), Eduardo de Mulder (President, IUGS), Zhang Hongren (President, IUGS), Peter Bobrowsky (Secretary-General, IUGS) and Werner Janoschek (Treasurer, IUGS), among many others.

The Medal that comes with the Harrison Award in 2012 will join two others awarded for very different experiences of mine. The United States Antarctic Service Medal (1974) came after publication of research findings but over a short space of time, while the International Consortium on Landslides David Varnes Medal (2007) came after more than a decade of field and laboratory based work on the landslide hazard with special reference to the high risk to human populations of slope failure in thick loess, especially in China. The James Harrison Award, however, comes in recognition of an "outstanding contribution" to an international scientific Union "over a considerable time span". The Harrison medal is thus distinctive in its object (an international scholarly institution) and the length of time involved. It will be held with genuine pride and with a mind to the opportunities and memories the Union has bestowed upon me since 1972.

\section{CALL FOR PAPERS}

Episodes is a quarterly science and news journal of the International Union of Geological Sciences (IUGS). It focuses on the publication of results of scientific research and other information addressing issues of interest to the global Earth science community. Special emphasis is given to topics involving geological aspects of population growth and economic development and their resulting impacts on or implications for society. As the principal publication of the IUGS, Episodes also carries information about IUGS scientific programs and activities to the extent necessary to communicate effectively with the worldwide IUGS constituency.

Contributions of the following types of manuscripts are solicited:

- Review papers

- News and views

- Letters to editor

- Information on training courses (especially those geared to participants from developing countries)

- Noteworthy new publications, including national or regional geological maps

Episodes also invites photos or other images for the front cover. Photos must be of high technical quality and tell an interesting geological story. A color transparency and one color print (at least $9 \mathrm{~cm} \times 12.6 \mathrm{~cm}$ ) are required for submission, which should be supplemented with a short explanatory paragraph (no more than 100 words).

Please address all contributions to: Dr. M. Jayananda

Editor, Episodes

Email: episodes.editor@gmail.com 